\title{
Określenie dynamicznej filtracji płuczek wiertniczych w warunkach HPHT z użyciem nowatorskiej metody pomiarowej
}

\begin{abstract}
W artykule przedstawiono analizę skuteczności działania środków ograniczających filtrację dynamiczną płuczek wiertniczych w warunkach HPHT. W toku przeprowadzonych badań sprawdzono działanie trzech środków: środka skrobiowego oraz dwóch rodzajów blokatorów węglanowych. Dodawane były one w różnych koncentracjach do dwóch rodzajów płuczek wiertniczych - płuczki polimerowo-potasowej oraz płuczki glikolowo-potasowej. Badania skuteczności ograniczania filtracji dynamicznej w warunkach HPHT przeprowadzone zostały z wykorzystaniem nowoczesnego aparatu Grace M2200, przy użyciu rdzeni o wielkości porów równej $60 \mu \mathrm{m}$. Ponadto określono wpływ badanych środków na podstawowe parametry płuczek wiertniczych. Uzyskane wyniki pozwalają stwierdzić, że najlepszą efektywnością w ograniczaniu filtracji spośród przebadanych kombinacji środków charakteryzował się zestaw: środek A - 3\%, środek B - 10\%, środek C - 10\%. Ponadto wykazano, że filtracja dynamiczna HPHT jest o wiele wyższa od filtracji statycznej, a różnice sięgają kilkuset procent. Zauważono również, że filtracja dynamiczna płuczki glikolowo-potasowej jest niższa niż płuczki polimerowo-potasowej.
\end{abstract}

Słowa kluczowe: płuczka wiertnicza, filtracja, filtracja dynamiczna, aparat M2200.

\section{Determination of dynamic filtration of drilling muds under HPHT conditions using an innovative measurement method}

\begin{abstract}
The article presents an analysis of the effectiveness of fluid loss agents in drilling muds under HPHT conditions. During the course of the tests, three agents were tested: starch and two types of carbonate blockers. They were added in different concentrations to two types of drilling muds: polymer-potassium mud and glycol-potassium mud. Research on the effectiveness of reducing dynamic filtration in HPHT was carried out using a modern apparatus Grace M2200, and $60 \mu \mathrm{m}$ pore size cores. In addition, the impact of the investigated agents on the basic parameters of drilling muds was determined. The obtained results allow to conclude, that the best efficiency in reducing the filtration among the tested combinations of agents, had the set containing the following agents: agent $\mathrm{A}-3 \%$, agent $\mathrm{B}-10 \%$, agent $\mathrm{C}-10 \%$. In addition, it has been demonstrated that dynamic filtration HPHT is much higher than static filtration, and the differences reach several hundred percent. Moreover, it was noted that the dynamic filtration of glycol-potassium drilling mud is lower than the filtration of polymer-potassium drilling mud.
\end{abstract}

Key words: drilling mud, filtration, dynamic filtration, M2200 apparatus.

\section{Wprowadzenie}

Wiercenie otworów w warunkach wysokich temperatur i ciśnień wymaga wykorzystania zaawansowanych systemów płuczek wiertniczych, w których szczególną uwagę należy zwrócić na dobór odpowiednich materiałów i środków chemicznych. Wymagania dotyczące płuczek wiertniczych, w szczególności stosowanych do dowiercania złóż w warunkach HPHT, to przede wszystkim zapewnienie, by uszkodze- nia strefy przyotworowej były jak najmniejsze, ustalenie odpowiednich parametrów reologicznych umożliwiających zawieszenie materiału obciążającego, odpowiednich właściwości inhibitacyjnych, smarnych oraz niskiej filtracji. Ważne jest równie utrzymywanie jak najniższej wartości filtracji płuczki wiertniczej, dlatego że w wyniku kontaktu przewiercanych skał, przede wszystkim iłowców i mułowców, z filtratem 
płuczkowym może następować przyspieszenie erozji ściany otworu wiertniczego, co w konsekwencji może prowadzić do zmniejszenia jej stabilności. Ponadto przedostanie się do skały dużej ilości filtratu może powodować zmniejszenie przepuszczalności strefy przyotworowej złoża. Kolejnym negatywnym czynnikiem jest powstawanie zbyt grubego osadu filtracyjnego, który powoduje nadmierne zaciąganie, przychwytywanie przewodu wiertniczego w wyniku ciśnienia różnicowego oraz nagłe wzrosty ciśnienia w otworze i tłokowanie. Jednym ze sposobów zapobiegania tym zjawiskom jest wykorzystanie w składzie płuczek wiertniczych środków pozwalają- cych na stworzenie szczelnego, słabo przepuszczalnego osadu filtracyjnego.

Badania filtracji płuczek wiertniczych prowadzone od wielu lat przyczyniają się do coraz lepszego poznania tego zjawiska. Nowoczesne urządzenia pomiarowe, pozwalające prowadzić badania w warunkach otworopodobnych pomagają dokładniej zrozumieć procesy zachodzące w otworze. Jednym z takich urządzeń jest wielofunkcyjny symulator wiercenia Grace M2200, który od niedawna znajduje się na wyposażeniu Zakładu Technologii Wiercenia Instytutu Nafty i Gazu - Państwowego Instytutu Badawczego.

\section{Filtracja płuczek wiertniczych}

Filtracją nazywa się odfiltrowanie płynu (najczęściej wody i rozpuszczonych w niej substancji chemicznych) z płuczki wiertniczej do przewiercanych formacji skalnych. Zjawisko filtracji ma miejsce, gdy płuczka wiertnicza wywiera ciśnienie na ścianę otworu wiertniczego oraz gdy przepuszczalność danej formacji pozwala na wnikanie płynu w otwartą przestrzeń komunikujących się porów. Jeżeli otwarta przestrzeń porowa jest wystarczająco duża, pierwszym efektem jest nagłe wtargnięcie w nią płuczki poprzez ścianę otworu wiertniczego. Dalsza część wnikającego płynu powoduje tworzenie się coraz grubszego osadu na ścianie otworu wiertniczego. Osad składa się z naturalnej fazy stałej pochodzącej z przewiercanych warstw oraz z fazy stałej dodatków, dodawanych przy sporządzaniu i obróbce płuczki. Ze względu na właściwości osadu filtracyjnego, ważniejsze jest, jaki kształt, rozmiar i rozmieszczenie ma faza stała, niż jaka jest jej zawartość [4, 10, 11]. Źle dobrany skład oraz niewłaściwe parametry płuczki wiertniczej mogą skutkować powstaniem osadu filtracyjnego złej jakości (zbyt grubego), co z kolei prowadzi do nadmiernej szybkości infiltrowania płynu w porowatą skałę oraz zbyt wysokiej objętości filtratu. Może to być przyczyną następujących problemów w otworze:

- zawężenia w otworze prowadzącego do powstania zjawiska zaciągania,

- nagłych wzrostów ciśnienia w czasie zapuszczania przewodu spowodowanych zmniejszeniem średnicy otworu,

- zwiększenia ciśnienia różnicowego, prowadzącego do przyklejenia przewodu poprzez zwiększenie powierzchni kontaktu w grubym osadzie,

- gorszej jakości cementowania spowodowanej niecałkowitym wytłoczeniem płuczki oraz obecnością zbyt grubego osadu,

- nadmiernej inwazji filtratu i zbyt grubej warstwy osadu stwarzających trudności w prawidłowej ocenie złoża.

Jak widać, większość wymienionych problemów jest pochodną zbyt grubego osadu filtracyjnego na ścianie otworu. Nadmierna filtracja rzutuje również na jakość i ocenę złoża.
Kiedy do złoża wniknie znaczna objętość filtratu, płyny złożowe mogą zostać odepchnięte ze strefy okołootworowej na taką odległość, że pomiary geofizyczne dadzą fałszywe wyniki. Również podczas opróbowywania, można uzyskać przypływ filtratu, który nie pozwala na właściwą ocenę rzeczywistego płynu w złożu. Jeżeli w złożu występują iły, woda z filtratu może powodować pęcznienie cząstek ilastych lub ich dyspersję, powodując tym samym ograniczenie przepuszczalności. Aby uniknąć problemów, przy wierceniu i udostępnianiu złoża, spowodowanych dużą filtracją, należy kontrolować osad - powinien on być jak najcieńszy i najmniej przepuszczalny $[4,5,10,11,20]$.

Znane są dwa rodzaje filtracji: dynamiczna i statyczna. Filtracja dynamiczna ma miejsce, gdy płuczka znajduje się w ruchu - w systemie cyrkulacyjnym. Filtracja statyczna natomiast występuje, gdy cyrkulacja płuczki jest zatrzymana. Filtracja dynamiczna różni się od filtracji statycznej tym, że przepływ płuczki wzdłuż ściany otworu wiertniczego może powodować erozję osadu utworzonego w wyniku procesu filtracji. Osad na ścianie otworu powiększa się w wyniku filtracji aż do momentu, gdy szybkość jego tworzenia i szybkość erozji, nawzajem się równoważą. Gdy grubość osadu osiągnie stan równowagi, szybkość filtracji utrzymywać się będzie na stałym poziomie. Przeciwnie jest w wypadku filtracji statycznej, przy której osad powiększa się stale wraz z upływem czasu. Równocześnie szybkość filtracji statycznej jest niższa niż dynamicznej. Dlatego też w procesie wiercenia otworu ważne jest aby regulować obie wartości: filtrację dynamiczną w celu kontroli ilości filtratu przechodzącego do formacji skalnej oraz filtrację statyczną, aby zapobiec tworzeniu zbyt grubego osadu.

Ważnymi czynnikami mającymi wpływ na wielkość filtracji są czas jej trwania oraz wielkość ciśnienia. Zgodnie z normą PN-EN ISO 10414-1, czas trwania pomiaru filtracji powinien wynosić 30 min. Przyjmuje się, że zależność objętości uzyskanego filtratu od czasu pomiaru można opisać następującym równaniem: 


$$
Q_{2}=Q_{1} \cdot \sqrt{\frac{t_{2}}{t_{1}}}
$$

gdzie:

$Q_{2}$ - nieznana objętość filtratu zmierzona w czasie $t_{2}\left[\mathrm{~cm}^{3}\right]$, $Q_{1}$ - znana objętość filtratu zmierzona w czasie $t_{1}\left[\mathrm{~cm}^{3}\right]$ [11].

Można zauważyć, że objętość filtratu wzrasta wprost proporcjonalnie do pierwiastka kwadratowego czasu pomiaru.

Ciśnienie jest kolejnym czynnikiem wpływającym na filtrację. Badanie filtracji tej samej płuczki przy różnych ci- śnieniach powoduje uzyskanie dwóch różnych wyników, proporcjonalnych do pierwiastka ilorazu wartości ciśnienia pomiaru:

$$
Q_{2}=Q_{1} \cdot \sqrt{\frac{p_{2}}{p_{1}}}
$$

gdzie:

$Q_{2}$ - nieznana objętość filtratu zmierzona przy ciśnieniu $p_{2}\left[\mathrm{~cm}^{3}\right]$, $Q_{1}$-znana objętość filtratu zmierzona przy ciśnieniu $p_{1}\left[\mathrm{~cm}^{3}\right]$, $p_{1}$ - ciśnienie, przy którym uzyskano objętość filtratu $Q_{1}[\mathrm{~Pa}]$, $p_{2}$ - ciśnienie, przy którym uzyskano objętość filtratu $Q_{2}[\mathrm{~Pa}][11]$.

\section{Dodatki regulujące filtrację}

W technologii płuczkowej substancje ograniczające filtrację w płuczkach wodnodyspersyjnych można podzielić na trzy główne grupy:

- środki pochodzenia mineralnego, takie jak iły, blokatory węglanowe lub nanomateriały,

- środki pochodzenia roślinnego, m.in. środki skrobiowe, środki celulozowe, zmielone łupiny,

- syntetyczne polimery.

\section{Ity}

Przez długi czas podstawowym środkiem do regulacji filtracji dla większości płuczek wiertniczych wodnodyspersyjnych była faza stała w postaci iłu. Punktem wyjściowym do dobrej regulacji filtracji jest odpowiedni rozkład wymiarów cząstek w płuczce. Płuczka zawiera zróżnicowane pod względem wielkości cząstki, a duża ich część ma rozmiary mniejsze lub równe mikronowi. W efekcie tak małych rozmiarów cząstek wnikających w wolne przestrzenie osadu filtracyjnego, ma on niską porowatość i przepuszczalność. Ił przemysłowy (bentonit) nie tylko powoduje obniżenie filtracji płuczek wiertniczych, wpływa również na podwyższenie lepkości płuczki $[4,11,12]$.

\section{Blokatory weglanowe}

Węglan wapnia $\left(\mathrm{CaCO}_{3}\right)$ występuje w przyrodzie jako składnik wielu minerałów (m.in. kalcyt) oraz skał (dolomit, kreda, marmur). Jako środek stosowany w technologii płuczkowej pozyskiwany jest przez zmielenie marmuru. Blokatory węglanowe występują w różnej ziarnistości, od kilku mikrometrów aż do $3 \mathrm{~mm}$. Odpowiednio dobrany rozmiar ziaren umożliwia uszczelnienie osadu filtracyjnego, skutecznie ograniczając migrację płynu i fazy stałej w głąb skał zbiornikowych w strefie przyotworowej. Z uwagi na zróżnicowaną wielkość cząstek, obojętność chemiczną produktu oraz łatwość usuwania ze ściany odwiertu, blokatory węglanowe są powszechnie stosowane nie tylko jako środki ograniczające filtrację, ale również jako materiały obciążające płyny wiertnicze do gęstości $1,5 \mathrm{~g} / \mathrm{cm}^{3}$ [17-19].

\section{Nanomaterialy}

Wśród stosowanych obecnie płuczek wiertniczych stosuje się tzw. inteligentne systemy pluczkowe. Są to ciecze nano, w których zawarte są cząstki w rozmiarze nanometrów. W zależności od liczby dodatków nanowymiarowych, można dokonać podziału płuczek na proste ciecze nano oraz zaawansowane ciecze nano. Płuczki zawierające w swoim składzie jeden rodzaj nanocząstek nazywane są prostymi nanopłuczkami, natomiast płuczki zawierające więcej niż jeden rodzaj nanocząstek definiowane są jako zaawansowane nanopłuczki $[1,2,22]$. Jednym z najczęściej wykorzystywanym w przemyśle nanomateriałem jest ditlenek krzemu (krzemionka $\mathrm{SiO}_{2}$ ). Dostępność tego materiału oraz specyficzne właściwości przyczyniły się do jego szerokiego wykorzystania. Jest on trwały w wodzie w podwyższonych temperaturach, a dodatkowo to dobry izolator. Krzemionka jest chemicznie inertna i ulega reakcjom jedynie z wrzącymi, stężonymi roztworami wodnymi $\mathrm{KOH}$ i $\mathrm{NaOH}$, stopionymi $\mathrm{Na}_{2} \mathrm{CO}_{3}$ i $\mathrm{K}_{2} \mathrm{CO}_{3}$ oraz fluorowodorem lub jego wodnymi roztworami. Średnica nanocząstek ditlenku krzemu produkowanego w przemyśle najczęściej zawiera się w przedziale od 5 do $1000 \mathrm{~nm}$, a ich powierzchnia właściwa może sięgać do około $500 \mathrm{~m}^{2} / \mathrm{g}$ [10,13-15]. Badania przeprowadzone przez M. Adela i innych [3, 6, 13-15] potwierdzają wysoką skuteczność nanomateriałów w obniżaniu filtracji płuczek wiertniczych oraz zmniejszaniu uszkodzenia naturalnej przepuszczalności skał zbiornikowych.

\section{Skrobia}

Jeżeli wykorzystanie koloidów mineralnych nie daje zadowalających wyników można użyć do obniżenia filtracji koloidów organicznych, takich jak skrobia. Podstawowymi źródłami pozyskiwania skrobi dla potrzeb przemysłu naftowego są kukurydza i ziemniaki. Odpowiednio spreparowane 
włókna skrobiowe zapewniają maksymalne obniżenie filtracji przez szybkie pęcznienie oraz zdolność do żelowania. Proces ten zachodzi zarówno w wodzie słodkiej, jak i słonej, bez względu na temperaturę i pH. Pod wpływem wody i ciepła ziarna skrobi ulegają rozerwaniu, a uwolniona amylaza w szybkim tempie absorbuje wodę, a następnie pęcznieje w workowate kształty przypominające swoją strukturą gąbkę. Zaabsorbowanie otaczającej wolnej wody powoduje zmniejszenie filtracji. Ponadto spęczniałe cząstki skrobiowe wypełniają wolne przestrzenie w osadzie filtracyjnym, zmniejszając filtrację $[4,11]$.

\section{Karboksymetyloceluloza (KMC)}

KMC jest koloidem organicznym stosowanym przy regulacji filtracji. Struktura KMC składa się z długich łańcuchów molekuł, które mogą ulegać polimeryzacji, tworząc struktury o odmiennych długościach. Istnieje kilka teorii wyjaśniających mechanizm obniżania filtracji przez karboksymetylocelulozę:

- klinowanie się długich łańcuchów polimerów w porach osadu filtracyjnego,

- zwijanie długich łańcuchów w kule, które stają się elementem uszczelniającym osad filtracyjny,

- pokrywanie cząstek fazy stałej cienką warstwą,

- zwiększenie lepkości fazy wodnej [4, 11].

\section{Polianionowa celuloza (PAC)}

Jest to środek organiczny obniżający filtrację przeznaczony głównie do płuczek z dużą koncentracją soli i niską zawartością fazy stałej. Składa się z polianionowych, długich łańcuchów polimerowych o wysokim ciężarze molekularnym $[4,11]$.

\section{Zmielone luski babki jajowatej}

Badania przeprowadzone przez A. Salmachi i innych $[16,21]$ dowodzą, że efektywnym środkiem obniżającym filtrację płuczek wiertniczych mogą być zmielone łuski ziaren, pochodzące z rośliny o nazwie babka jajowata. Do tej pory łuski babki jajowatej były szeroko stosowane w medycynie i przemyśle spożywczym. W pracy [16] oceniono efektywność tego środka jako przyjaznego dla środowiska dodatku do płuczek wodnodyspersyjnych. Stwierdzono, że stężenie wynoszące $0,75 \div 1 \%$ zmielonych łusek nadaje cieczy właściwości reologiczne, równoważne wykorzystaniu 5\% bentonitu. Środek dodany do wody bardzo szybko dysperguje, tworząc żelową strukturę. Przeprowadzone badania wykazały, że roztwór o stężeniu 1\% środka charakteryzował się 13-proc. obniżeniem filtracji w stosunku do roztworu bentonitu o stężeniu 5\%. Oprócz tworzenia żelowej struktury absorbującej wolną wodę z otoczenia, nierozpuszczalne części łusek tworzą bardzo cienki placek filtracyjny, który blokując duże pory przyczynia się do ograniczenia filtracji.

\section{Zakres badań}

W pierwszym etapie badań wytypowane zostały trzy środki o właściwościach ograniczających filtrację płuczek wiertniczych:

- środek skrobiowy A,

- blokator węglanowy B,

- blokator węglanowy C.

Kolejnym krokiem był dobór płuczek wiertniczych, stosowanych obecnie do głębokich wierceń w warunkach HPHT, które miały być modyfikowane przez dodatek środków ograniczających filtrację. Wybrano płuczki o podwójnym inhibitowaniu polimerowo-jonowym: płuczkę polimerowo-potasową oraz płuczkę glikolowo-potasową. Obydwa rodzaje płuczek wykorzystanych w badaniach laboratoryjnych opierały się na tym samym zestawie polimerów strukturotwórczych. Były to: PAC LV, PAC R, XCD oraz Polofix LV. Podobnie w obydwu rodzajach płuczek jednym z użytych inhibitorów hydratacji łupków był chlorek potasu, który pełnił funkcję jonowego inhibitora hydratacji skał ilastych. W płuczce glikolowo-potasowej rolę inhibitora polimerowego odgrywał dwuskładnikowy układ blokowego kopolimeru tlenku etylenu i tlenku propylenu w połączeniu z oksyetylenowanym trójglicerydem kwasu rycynolowego. W przypadku płuczki polimerowo-potasowej funkcję inhibitora polimerowego pełni częściowo hydrolizowany poliakryloamid (PHPA).

W kolejnym etapie realizacji zadania określono wpływ badanych środków ograniczających filtrację na podstawowe parametry technologiczne płuczek, takie jak: właściwości reologiczne, gęstość, filtracja API, pH. Ponadto płuczki poddano badaniu reometrem Anton Paar MCR 301, polegającym na zmierzeniu parametrów reologicznych płuczek w zakresie temperatur $20^{\circ} \mathrm{C}-100^{\circ} \mathrm{C}-20^{\circ} \mathrm{C}$, w odstępie co $20^{\circ} \mathrm{C}$. Uzyskane w ten sposób wyniki posłużyły do oszacowania wytrzymałości termicznej badanych płuczek.

Następnie mierzono wartość filtracji dynamicznej w warunkach HPHT z użyciem wielofunkcyjnego symulatora wiercenia Grace M2200 w płuczkach wyjściowych oraz w płuczkach z dodatkiem poszczególnych środków ograniczających filtrację. Do badania filtracji użyte zostały rdzenie, których średnica porów wynosiła $60 \mu \mathrm{m}$. Pomiary przeprowadzane były w temperaturze $100^{\circ} \mathrm{C}$, czyli w warunkach zbliżonych do tych panujących w głębokich otworach. 


\section{Pomiar filtracji dynamicznej w warunkach HPHT}

Do pomiaru filtracji dynamicznej wykorzystano unikatowy na skalę światową aparat Grace M2200 HPHT. Umożliwia on przeprowadzenie pomiaru smarności i filtracji dynamicznej płuczek wiertniczych w symulowanych warunkach otworowych. Dodatkową funkcją jest pomiar szybkości wiercenia w rzeczywistych próbkach skał przy pomocy miniaturowego świdra wiertniczego. Aparat umożliwia realistyczne symulowanie warunków otworowych dzięki dużemu zakresowi temperatury roboczej $\left(\right.$ do $260^{\circ} \mathrm{C}$ ) oraz ciśnienia (do 13,8 MPa). Obsługa odbywa się przy użyciu nowoczesnego oprogramowania komputerowego M2200 PC.

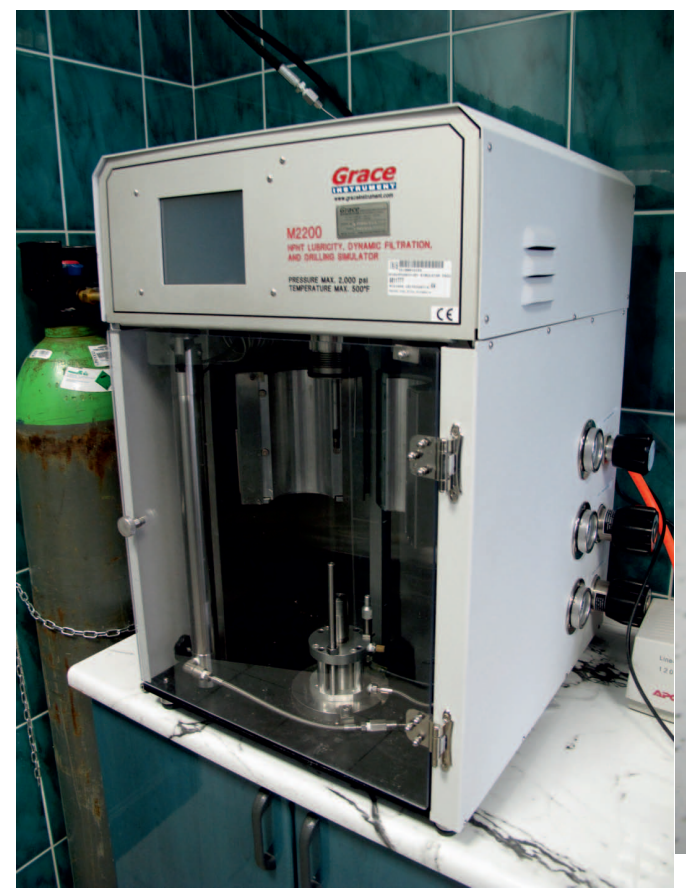

Fot. 1. Aparat Grace M2200 HPHT

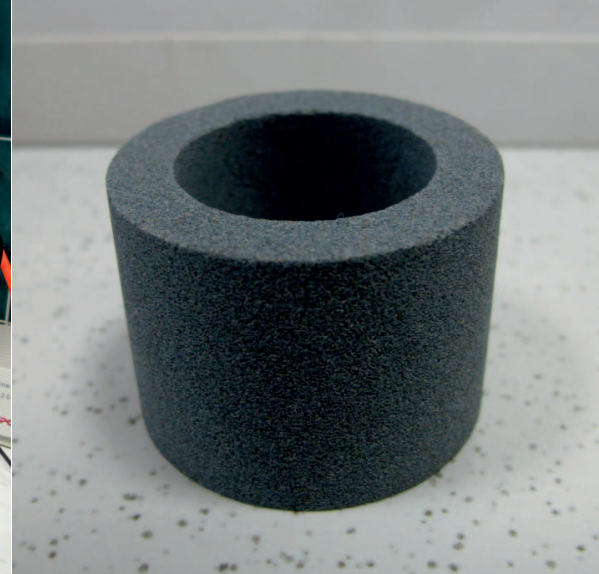

Fot. 2. Rdzeń pierścieniowy o średnicy porów $60 \mu \mathrm{m}$

wie aktualnego położenia tłoczka w kolumnie obliczana jest objętość filtratu. W trakcie trwania pomiaru, wewnątrz otworu rdzenia z zadaną prędkością wiruje rotor symulujący przewód wiertniczy w otworze wiertniczym. Całość jest zamknięta w szczelnej komorze, która z kolei otoczona jest płaszczem podgrzewającym cały układ do zadanej temperatury.

Pomiar filtracji dynamicznej płuczki wiertniczej rozpoczął się od umieszczenia porowatego rdzenia pierścieniowego w uchwycie, gdzie następnie został doszczelniony gumowymi uszczelkami. Rdzenie użyte podczas badań charakteryzowały się średnicą porów równą $60 \mu \mathrm{m}$. Po umieszczeniu rdzenia w uchwycie zabezpieczano go poprzez dokręcenie stalowym pierścieniem, uniemożliwiającym przesunięcie lub obrót próbki. Następnie uchwyt z zamocowanym rdzeniem wkręcano do komory, do której nalewano $325 \mathrm{~cm}^{3}$ badanej płuczki. Całość była przykręcana do gniazda aparatu, gdzie na wale obrotowym zamocowany był rotor. Kolejnym krokiem było przygotowanie w programie M2200 PC odpowiedniej sekwencji kroków pomiarowych, czyli zadanie wymaganej temperatury do jakiej podgrzana ma być płuczka oraz obrotów rotora. Po osiągnięciu wymaganej temperatury, za pomocą pokręteł umieszczonych na obudowie aparatu regulowano ciśnienie oddziałujące na płuczkę znajdującą się w komorze pomiarowej oraz przeciwciśnienie w kolumnie pomiarowej. Ciśnienia uzyskiwane są $\mathrm{z}$ butli z azotem. Badania przeprowadzone w toku realizacji pracy

Podczas pomiaru filtracji dynamicznej, na płuczkę wiertniczą oddziałuje ciśnienie, co powoduje wnikanie filtratu w cylindryczny rdzeń wykonany z porowatego materiału. Filtrat ten przenika przez ściankę rdzenia, skąd wtłaczany jest do kolumny pomiarowej, powodując przesunięcie się tłoczka, którego ruch jest ciągle rejestrowany przez urządzenie. Na podsta- charakteryzowały się następującymi parametrami:

- średnica porów rdzenia pierścieniowego $-60 \mu \mathrm{m}$,

- temperatura płuczki $-100^{\circ} \mathrm{C}$,

- ciśnienie płuczki - 100 psi (0,69 MPa),

- prędkość obrotowa rotora $-250 \mathrm{obr} / \mathrm{min}$.,

- czas pomiaru-30 min.

\section{Omówienie wyników badań}

Bazowa płuczka polimerowo-potasowa oznaczona została cyfrą 1. Charakteryzowała się lepkością plastyczną równą $66,1 \mathrm{mPa} \cdot \mathrm{s}$, lepkością pozorną o wartości $106,8 \mathrm{mPa} \cdot \mathrm{s}$ oraz granicą płynięcia wynoszącą 39,0 Pa. Ponadto gęstość płuczki wynosiła $1,04 \mathrm{~g} / \mathrm{cm}^{3}$, a filtracja API $-6,4 \mathrm{~cm}^{3}$. Podniesienie temperatury płuczki do $100^{\circ} \mathrm{C}$ spowodowało, że lepkość plastyczna i lepkość pozorna uległy obniżeniu do wartości odpowiednio $26,3 \mathrm{mPa} \cdot \mathrm{s}$ i $36,7 \mathrm{mPa} \cdot \mathrm{s}$, natomiast granica płynięcia wynosiła 9,8 Pa. Skład płuczki bazowej modyfikowano poprzez dodatek środków B i C w różnych stężeniach, a powstałe w ten sposób płuczki oznaczono cyframi 2-7. Ich skład i parametry przedstawiono $\mathrm{w}$ tablicy 1 .

Płuczkę glikolowo-potasową przygotowano na podstawie tego samego zestawu polimerów strukturotwórczych, jakim 
Tablica 1. Skład oraz parametry płuczek polimerowo-potasowych modyfikowanych środkami ograniczającymi filtrację

\begin{tabular}{|c|c|c|c|c|c|c|c|c|c|c|c|}
\hline \multirow{3}{*}{$\begin{array}{c}\mathrm{Nr} \\
\text { płuczki }\end{array}$} & \multirow{3}{*}{\multicolumn{2}{|c|}{ Skład płuczki wiertniczej }} & \multicolumn{4}{|c|}{$\begin{array}{l}\text { Lepkość } \\
{[\mathrm{mPa} \cdot \mathrm{s}]}\end{array}$} & \multirow{2}{*}{\multicolumn{2}{|c|}{$\begin{array}{c}\text { Granica płynięcia } \\
{[\mathrm{Pa}]}\end{array}$}} & \multirow{3}{*}{$\begin{array}{c}\text { Wytrzymałość } \\
\text { strukturalna I/II } \\
{[\mathrm{Pa}]}\end{array}$} & \multirow{3}{*}{$\begin{array}{c}\text { Filtracja } \\
\text { API } \\
{\left[\mathrm{cm}^{3}\right]}\end{array}$} & \multirow{3}{*}{$\mathrm{pH}$} \\
\hline & & & \multicolumn{2}{|c|}{$\eta_{p l}$} & \multicolumn{2}{|c|}{$\eta_{s}$} & & & & & \\
\hline & & & $20^{\circ} \mathrm{C}$ & $100^{\circ} \mathrm{C}$ & $20^{\circ} \mathrm{C}$ & $100^{\circ} \mathrm{C}$ & $20^{\circ} \mathrm{C}$ & $100^{\circ} \mathrm{C}$ & & & \\
\hline 1. & $\begin{array}{c}\text { Biostat } \\
\text { PAC LV } \\
\text { PAC R } \\
\text { XCD } \\
\text { Polofix LV } \\
\text { Stabpol S } \\
\text { KCl } \\
\text { + Srodek A }\end{array}$ & $\begin{array}{l}0,10 \% \\
0,50 \% \\
0,20 \% \\
0,25 \% \\
0,75 \% \\
0,30 \% \\
5,00 \% \\
3,00 \% \\
\end{array}$ & 66,1 & 26,3 & 106,8 & 36,6 & 39,0 & 9,8 & $5,9 / 7,6$ & 6,4 & 9,4 \\
\hline 2. & $\begin{array}{c}\text { Płuczka } 1 \\
+ \text { Środek B }\end{array}$ & $5,00 \%$ & 67,2 & 27,4 & 108,8 & 37,9 & 39,7 & 9,9 & $6,6 / 7,8$ & 5,2 & 9,2 \\
\hline 3. & $\begin{array}{c}\text { Płuczka } 1 \\
+ \text { Środek B } \\
\end{array}$ & $10,00 \%$ & 72,3 & 28,2 & 11,6 & 37,6 & 44,2 & 8,9 & $6,6 / 7,8$ & 4,6 & 9,1 \\
\hline 4. & $\begin{array}{l}\text { Płuczka } 1 \\
+ \text { Środek B } \\
+ \text { Środek C } \\
\end{array}$ & $\begin{array}{l}5,00 \% \\
5,00 \% \\
\end{array}$ & 69,4 & 27,4 & 109,8 & 38,2 & 38,6 & 10,3 & $7,0 / 8,4$ & 5,0 & 9,1 \\
\hline 5. & $\begin{array}{l}\text { Płuczka } 1 \\
+ \text { Środek B } \\
+ \text { Środek C }\end{array}$ & $\begin{array}{c}5,00 \% \\
10,00 \%\end{array}$ & 74,7 & 27,6 & 113,7 & 37,8 & 37,3 & 9,6 & $7,8 / 9,4$ & 4,8 & 9,2 \\
\hline 6. & $\begin{array}{l}\text { Płuczka } 1 \\
+ \text { Środek B } \\
+ \text { Środek C } \\
\end{array}$ & $\begin{array}{c}10,00 \% \\
5,00 \% \\
\end{array}$ & 72,7 & 25,9 & 112,7 & 33,7 & 38,2 & 7,5 & $5,9 / 7,5$ & 3,7 & 9,1 \\
\hline 7. & $\begin{array}{l}\text { Płuczka } 1 \\
+ \text { Środek B } \\
+ \text { Środek C }\end{array}$ & $\begin{array}{l}10,00 \% \\
10,00 \%\end{array}$ & 7,7 & 26,1 & 119,6 & 34,7 & 39,0 & 8,2 & $8,1 / 9,9$ & 3,2 & 9,3 \\
\hline
\end{tabular}

charakteryzowała się płuczka polimerowo-potasowa. W jej składzie znajdował się dodatek oksyetylenowanego trójglicerydu kwasu rycynolowego (R26) w stężeniu 1\% oraz blokowy kopolimer tlenku etylenu i tlenku propylenu (R2100) w stężeniu 3\%. Tak otrzymana płuczka oznaczona została cyfrą 8 i nazywana jest dalej bazową płuczką glikolowo-potasową. Cechowała się ona lepkością plastyczną równą $55,5 \mathrm{mPa} \cdot \mathrm{s}$, lepkością pozorną o wartości $85,3 \mathrm{mPa} \cdot \mathrm{s}$ oraz granicą pły- no w tablicy 2 .

Tablica 2. Skład oraz parametry płuczek glikolowo-potasowych modyfikowanych środkami ograniczającymi filtrację

\begin{tabular}{|c|c|c|c|c|c|c|c|c|c|c|c|}
\hline \multirow{3}{*}{$\begin{array}{c}\mathrm{Nr} \\
\text { płuczki }\end{array}$} & \multirow{3}{*}{\multicolumn{2}{|c|}{ Skład płuczki wiertniczej }} & \multicolumn{4}{|c|}{$\begin{array}{l}\text { Lepkość } \\
{[\mathrm{mPa} \cdot \mathrm{s}]}\end{array}$} & \multirow{2}{*}{\multicolumn{2}{|c|}{$\begin{array}{l}\text { Granica płynięcia } \\
{[\mathrm{Pa}]}\end{array}$}} & \multirow{3}{*}{$\begin{array}{c}\text { Wytrzymałość } \\
\text { strukturalna I/II } \\
{[\mathrm{Pa}]}\end{array}$} & \multirow{3}{*}{$\begin{array}{c}\text { Filtracja } \\
\text { API } \\
{\left[\mathrm{cm}^{3}\right]}\end{array}$} & \multirow{3}{*}{$\mathrm{pH}$} \\
\hline & & & \multicolumn{2}{|c|}{$\eta_{p l}$} & \multicolumn{2}{|c|}{$\eta_{s}$} & & & & & \\
\hline & & & $20^{\circ} \mathrm{C}$ & $100^{\circ} \mathrm{C}$ & $20^{\circ} \mathrm{C}$ & $100^{\circ} \mathrm{C}$ & $20^{\circ} \mathrm{C}$ & $100^{\circ} \mathrm{C}$ & & & \\
\hline 8. & $\begin{array}{c}\text { Biostat } \\
\text { PAC LV } \\
\text { PAC R } \\
\text { XCD } \\
\text { Polofix LV } \\
\text { R26 } \\
\text { R2100 } \\
\text { KCl } \\
+ \text { Srodek A }\end{array}$ & $\begin{array}{l}0,10 \% \\
0,50 \% \\
0,20 \% \\
0,25 \% \\
0,75 \% \\
1,00 \% \\
3,00 \% \\
5,00 \% \\
3,00 \%\end{array}$ & 55,5 & 23,1 & 85,3 & 32,5 & 28,5 & 8,9 & $5,0 / 6,9$ & 5,8 & 9,5 \\
\hline 9. & $\begin{array}{c}\text { Płuczka } 1 \\
+ \text { Środek B }\end{array}$ & $5,00 \%$ & 54,3 & 23,1 & 83,9 & 33,4 & 28,3 & 9,8 & $5,4 / 7,9$ & 4,4 & 9,4 \\
\hline
\end{tabular}

nięcia wynoszącą 28,5 Pa. Ponadto gęstość płuczki wynosiła $1,04 \mathrm{~g} / \mathrm{cm}^{3}$, a filtracja API $-5,8 \mathrm{~cm}^{3}$. Podniesienie temperatury płuczki do $100^{\circ} \mathrm{C}$ spowodowało, że lepkość plastyczna i lepkość pozorna uległy obniżeniu do wartości, odpowiednio: $23,1 \mathrm{mPa} \cdot \mathrm{s}$ i $32,5 \mathrm{mPa} \cdot \mathrm{s}$, natomiast granica płynięcia wynosiła 8,9 Pa. Skład i parametry płuczki bazowej oraz jej modyfikacji środkami ograniczającymi filtrację przedstawio- 
cd. Tablica 2

\begin{tabular}{|c|c|c|c|c|c|c|c|c|c|c|c|}
\hline \multirow{3}{*}{$\begin{array}{c}\mathrm{Nr} \\
\text { płuczki }\end{array}$} & \multirow{3}{*}{\multicolumn{2}{|c|}{ Skład płuczki wiertniczej }} & \multicolumn{4}{|c|}{$\begin{array}{l}\text { Lepkość } \\
{[\mathrm{mPa} \cdot \mathrm{s}]}\end{array}$} & \multirow{2}{*}{\multicolumn{2}{|c|}{$\begin{array}{c}\text { Granica płynięcia } \\
{[\mathrm{Pa}]}\end{array}$}} & \multirow{3}{*}{$\begin{array}{c}\text { Wytrzymałość } \\
\text { strukturalna I/II } \\
{[\mathrm{Pa}]}\end{array}$} & \multirow{3}{*}{$\begin{array}{c}\text { Filtracja } \\
\text { API } \\
{\left[\mathrm{cm}^{3}\right]}\end{array}$} & \multirow{3}{*}{$\mathrm{pH}$} \\
\hline & & & \multicolumn{2}{|c|}{$\eta_{p l}$} & \multicolumn{2}{|c|}{$\eta_{s}$} & & & & & \\
\hline & & & $20^{\circ} \mathrm{C}$ & $100^{\circ} \mathrm{C}$ & $20^{\circ} \mathrm{C}$ & $100^{\circ} \mathrm{C}$ & $20^{\circ} \mathrm{C}$ & $100^{\circ} \mathrm{C}$ & & & \\
\hline 10. & $\begin{array}{c}\text { Płuczka } 1 \\
+ \text { Środek B }\end{array}$ & $10,00 \%$ & 55,7 & 24,9 & 88,7 & 34,1 & 31,6 & 8,8 & $5,7 / 7,6$ & 3,4 & 9,4 \\
\hline 11. & $\begin{array}{l}\text { Płuczka } 1 \\
+ \text { Środek B } \\
+ \text { Środek C }\end{array}$ & $\begin{array}{l}5,00 \% \\
5,00 \%\end{array}$ & 56,8 & 23,7 & 86,8 & 33,7 & 28,7 & 9,6 & $5,3 / 7,4$ & 4,0 & 9,3 \\
\hline 12. & $\begin{array}{c}\text { Płuczka } 1 \\
+ \text { Środek B } \\
+ \text { Środek C }\end{array}$ & $\begin{array}{c}5,00 \% \\
10,00 \%\end{array}$ & 61,3 & 22,0 & 89,6 & 31,2 & 27,0 & 9,4 & $7,1 / 8,9$ & 3,8 & 9,3 \\
\hline 13. & $\begin{array}{l}\text { Płuczka } 1 \\
+ \text { Środek B } \\
+ \text { Środek C }\end{array}$ & $\begin{array}{c}10,00 \% \\
5,00 \%\end{array}$ & 70,6 & 26,3 & 104,9 & 36,0 & 32,8 & 9,3 & $7,4 / 12,1$ & 2,6 & 9,3 \\
\hline 14. & $\begin{array}{c}\text { Płuczka } 1 \\
+ \text { Środek B } \\
+ \text { Środek C }\end{array}$ & $\begin{array}{l}10,00 \% \\
10,00 \%\end{array}$ & 68,4 & 24,3 & 102,9 & 34,7 & 33,0 & 9,9 & $7,6 / 130$ & 2,5 & 9,3 \\
\hline
\end{tabular}

Na rysunkach 1-7 przedstawiono wykresy objętości filtratu w funkcji czasu, uzyskanych podczas badań płuczek polimerowo-potasowych. Analizując wykresy, można stwierdzić, że we wszystkich przypadkach początkowe minuty pomiaru cechowały się dużą dynamiką narastania objętości filtratu. Następnie zaczynał się etap budowania osadu filtracyjnego na ściance rdzenia pomiarowego, co na wykresach widać wyraźnie po coraz mniejszym tempie narastania objętości filtratu. Gdy osad stawał się nieprzepuszczalny dla filtratu, krzywe stabilizowały się na pewnym poziomie.

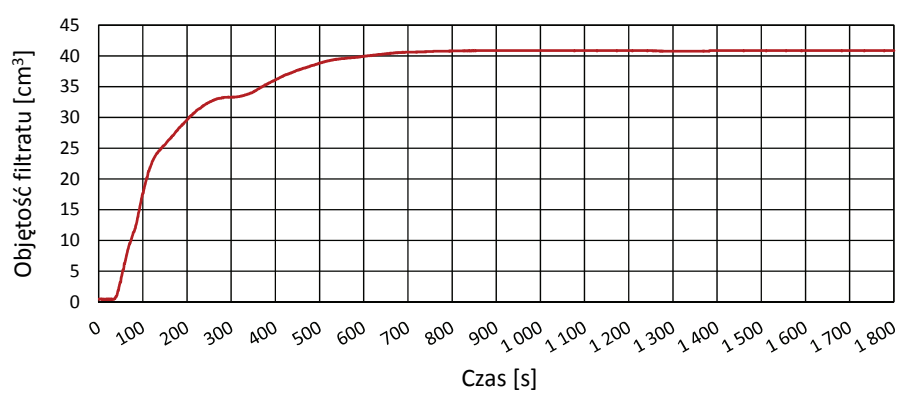

Rys. 1. Krzywa przyrostu objętości filtratu uzyskanego z płuczki $1 \mathrm{w}$ funkcji czasu

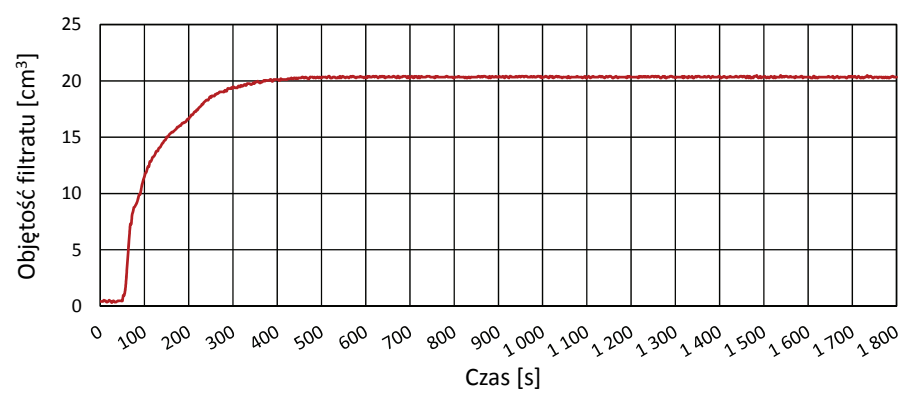

Rys. 2. Krzywa przyrostu objętości filtratu uzyskanego z płuczki 2 w funkcji czasu

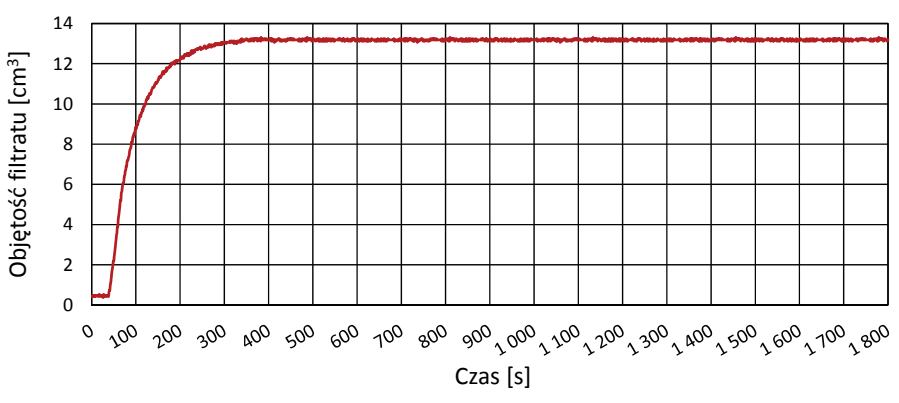

Rys. 3. Krzywa przyrostu objętości filtratu uzyskanego z płuczki 3 w funkcji czasu

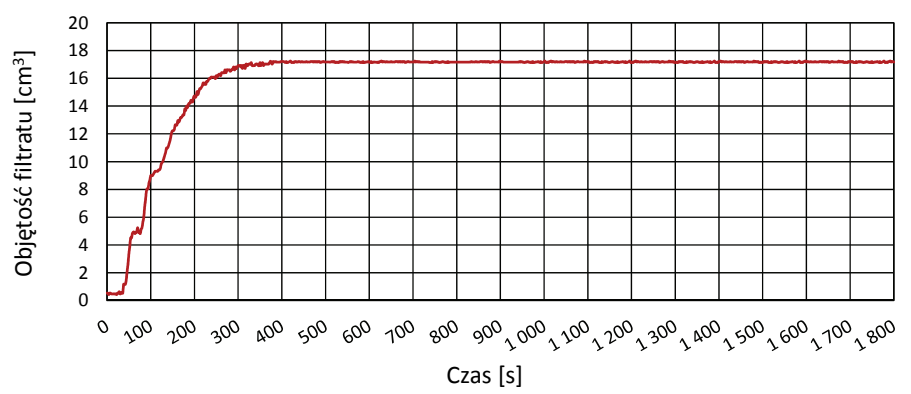

Rys. 4. Krzywa przyrostu objętości filtratu uzyskanego z płuczki $4 \mathrm{w}$ funkcji czasu

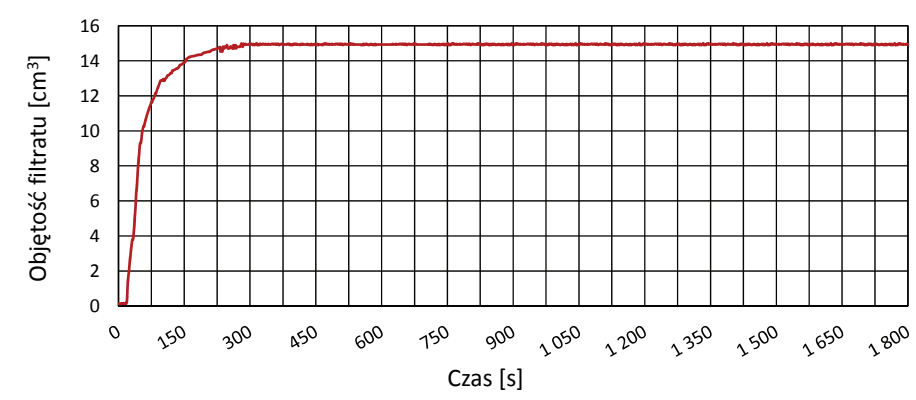

Rys. 5. Krzywa przyrostu objętości filtratu uzyskanego z płuczki $5 \mathrm{w}$ funkcji czasu 


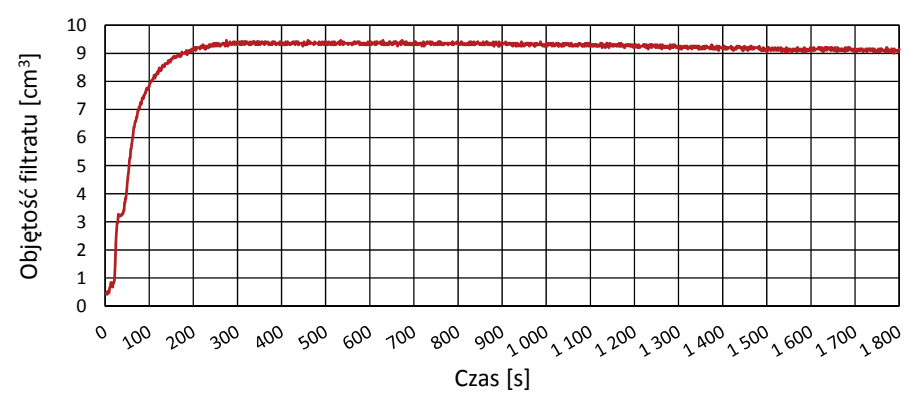

Rys. 6. Krzywa przyrostu objętości filtratu uzyskanego z płuczki $6 \mathrm{w}$ funkcji czasu

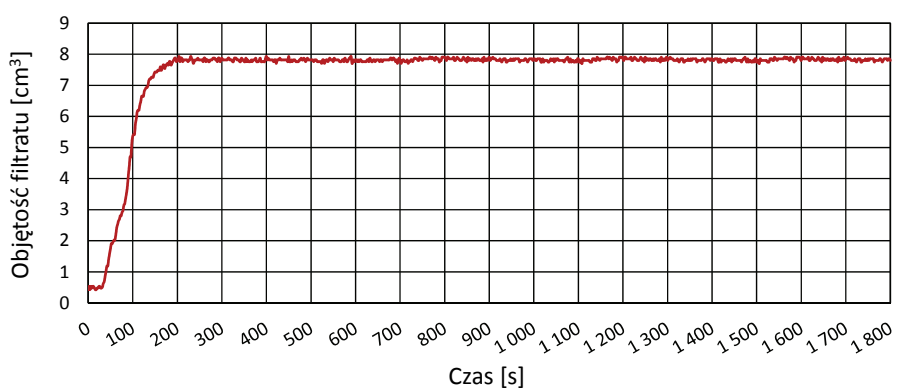

Rys. 7. Krzywa przyrostu objętości filtratu uzyskanego z płuczki $7 \mathrm{w}$ funkcji czasu
W tablicy 3 zestawiono wyniki pomiarów filtracji dynamicznej HPHT płuczek 1-7, przeprowadzonych z użyciem aparatu M2200. Bazowa płuczka polimerowo-potasowa (płuczka 1) charakteryzowała się filtracją równą $40,9 \mathrm{~cm}^{3}$. Największą efektywność w ograniczaniu filtracji zapewniała płuczka 7. Miała ona w swoim składzie aż $20 \%$ blokatorów węglanowych (10\% środka B oraz $10 \%$ środka C), a wartość filtracji po 30 min. wynosiła $7,8 \mathrm{~cm}^{3}$, czyli o $80,9 \%$ mniej niż w płuczce bazowej. $Z$ kolei najmniej efektywna była płuczka 2 , mająca w składzie $5 \%$ środka B, której filtracja miała wartość $20,3 \mathrm{~cm}^{3}$ - o 50,4\% mniej niż w płuczce bazowej. $Z$ tablicy 3 można również odczytać czas powstania nieprzepuszczalnego osadu filtracyjnego w poszczególnych płuczkach. Najdłuższy czas, około 800 s, odnotowano podczas badania płuczki bazowej. Najkrótszym czasem (około $200 \mathrm{~s}$ ) charakteryzowała się płuczka 7, zawierająca $20 \%$ blokatorów.

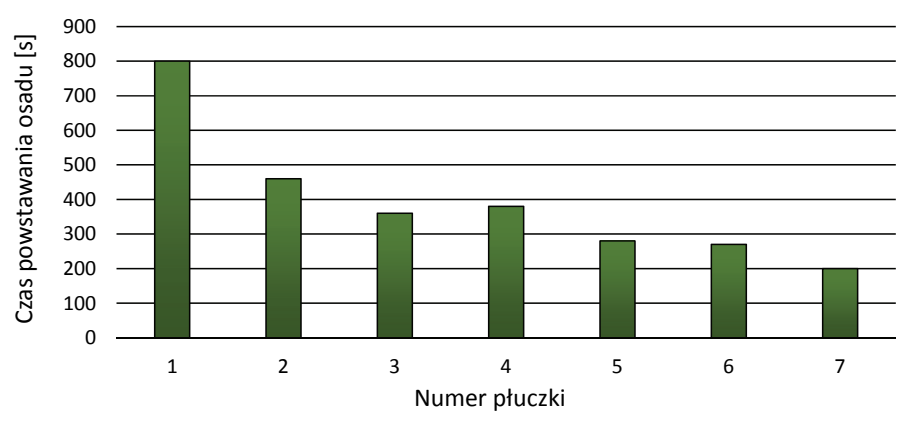

Rys. 8. Czas budowania nieprzepuszczalnego osadu w płuczkach 1-7

W tablicy 4 oraz na rysunku 9 zestawiono ze sobą wyniki pomiaru filtracji statycznej API w temperaturze $20^{\circ} \mathrm{C}$ z wynikami pomiaru filtracji dynamicznej HTHP w temperaturze $100^{\circ} \mathrm{C}$.
Tablica 4. Porównanie wyników badania filtracji API w $20^{\circ} \mathrm{C}$ oraz dynamicznej filtracji HPHT w $100^{\circ} \mathrm{C}$ płuczek 1-7

ach polimerowo-potasowych

\begin{tabular}{|c|c|c|c|c|c|c|}
\hline \multicolumn{7}{|c|}{ Nr płuczki } \\
\hline 1 & 2 & 3 & 4 & 5 & 6 & 7 \\
\hline $\mathbf{4 0 , 9}$ & 20,3 & 13,2 & 17,2 & 14,9 & 9,1 & 7,8 \\
\hline- & $-50,4$ & $-67,7$ & $-57,9$ & $-63,6$ & $-77,8$ & $-80,9$ \\
\hline $\mathbf{8 0 0}$ & 460 & 360 & 380 & 280 & 270 & 200 \\
\hline- & $-42,5$ & $-55,0$ & $-52,5$ & $-65,0$ & $-66,3$ & $-75,0$ \\
\hline
\end{tabular}

Wartości filtracji dynamicznej były zdecydowanie wyższe niż wartości filtracji API, można jednak zauważyć, że wraz ze wzrostem zawartości substancji ograniczających filtrację różnica staje się coraz mniejsza. W płuczce 1, w której nie było blokatorów węglanowych, filtracja dynamiczna miała wartość $40,9 \mathrm{~cm}^{3}$, a więc była o $540 \%$ wyższa od filtracji API. Z kolei w płuczce 7 filtracja dynamiczna było wyższa od filtracji API o około $144 \%$.

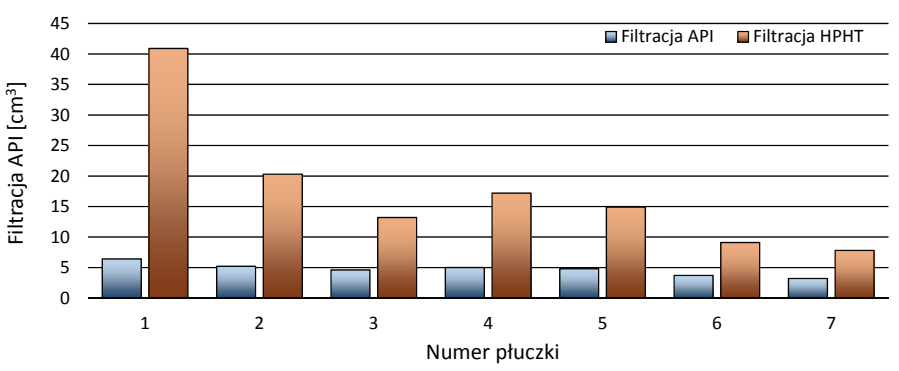

Rys. 9. Graficzne porównanie wyników badania filtracji API oraz dynamicznej filtracji HPHT płuczek 1-7

Na rysunkach 10-16 przedstawiono wykresy objętości filtratu uzyskanego z płuczek glikolowo-potasowych. Analogicznie do badań przeprowadzonych na płuczkach polimerowo-potasowych, tutaj również można zaobserwować etap 


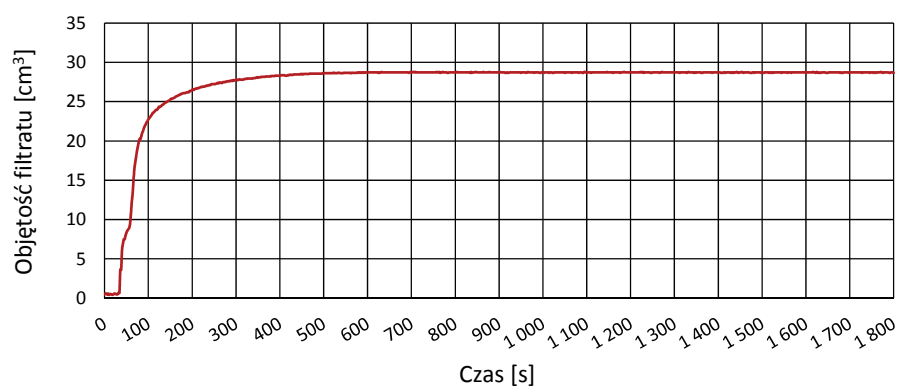

Rys. 10. Krzywa przyrostu objętości filtratu uzyskanego z płuczki $8 \mathrm{w}$ funkcji czasu

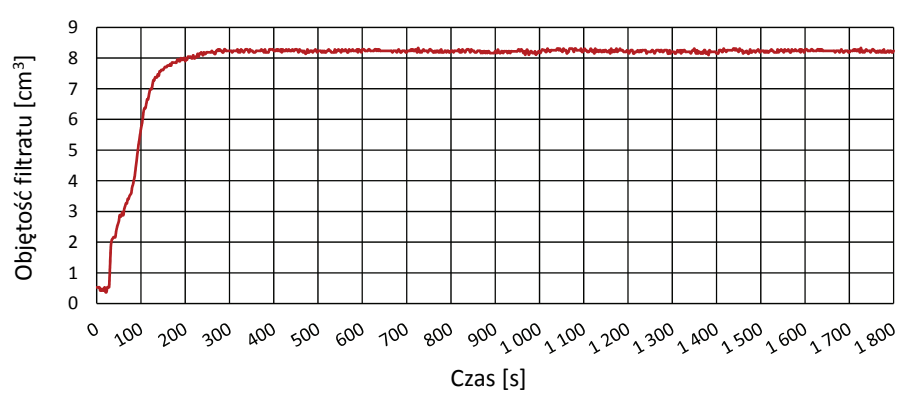

Rys. 12. Krzywa przyrostu objętości filtratu uzyskanego z płuczki $10 \mathrm{w}$ funkcji czasu

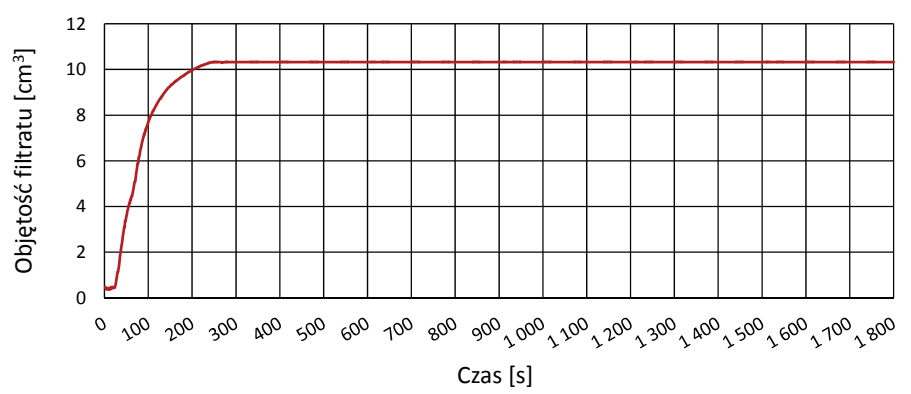

Rys. 14. Krzywa przyrostu objętości filtratu uzyskanego z płuczki $12 \mathrm{w}$ funkcji czasu

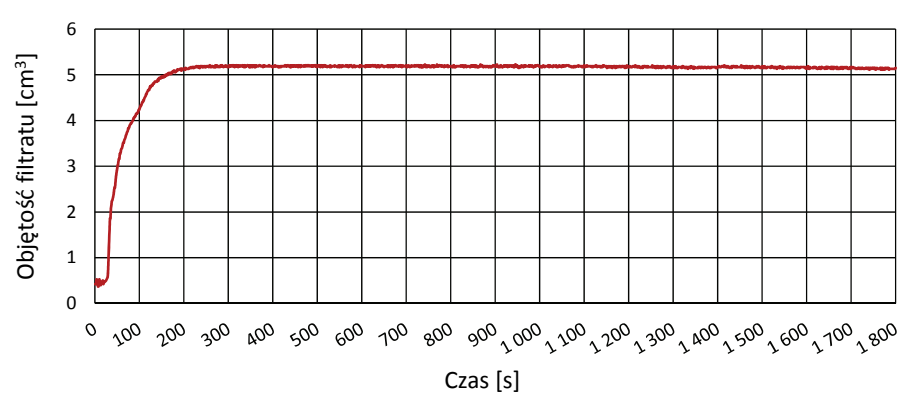

Rys. 16. Krzywa przyrostu objętości filtratu uzyskanego z płuczki $14 \mathrm{w}$ funkcji czasu

dynamicznego wzrostu objętości filtratu, następnie etap tworzenia się osadu filtracyjnego, który następnie po uzyskaniu całkowitej szczelności blokuje dalsze wnikanie fazy wodnej z płuczek wiertniczych.

W tablicy 5 zestawiono wyniki pomiarów filtracji dynamicznej HPHT płuczek 8-14. Płuczka nr 8, do której odnoszo-

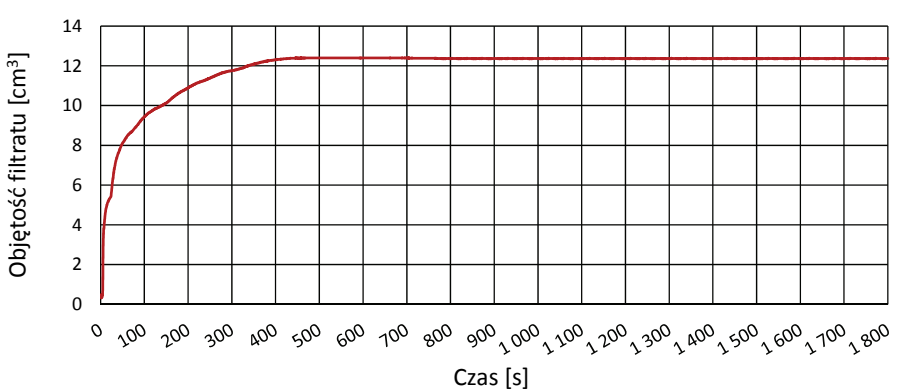

Rys. 11. Krzywa przyrostu objętości filtratu uzyskanego z płuczki 9 w funkcji czasu

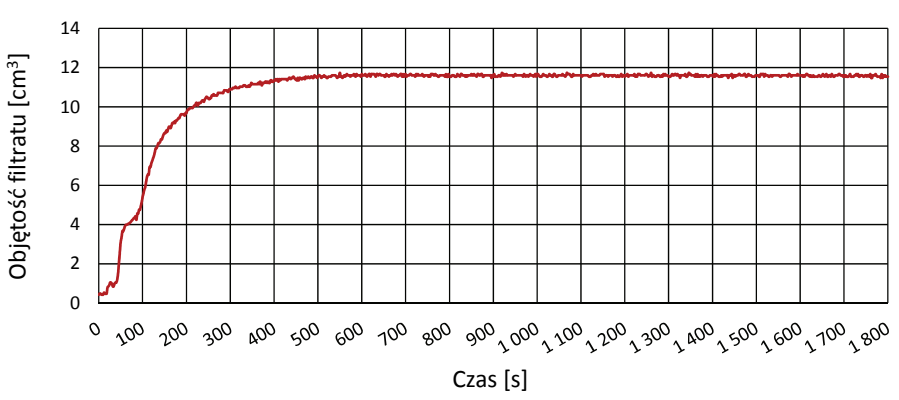

Rys. 13. Krzywa przyrostu objętości filtratu uzyskanego z płuczki $11 \mathrm{w}$ funkcji czasu

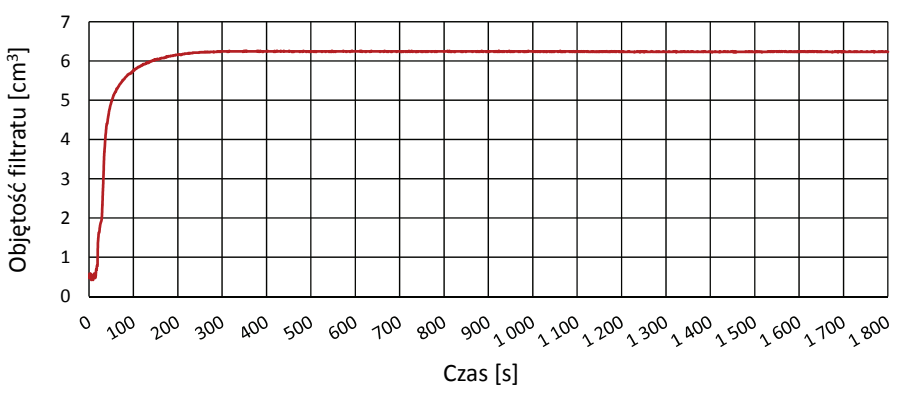

Rys. 15. Krzywa przyrostu objętości filtratu uzyskanego z płuczki 13 w funkcji czasu

no pozostałe wyniki, cechowała się filtracją równą $28,7 \mathrm{~cm}^{3}$. Najniższą wartość filtracji odnotowano podczas pomiaru płuczki nr 14. Było to $5,2 \mathrm{~cm}^{3}$, czyli o $81,9 \%$ mniej niż w płuczce bazowej. Najmniej efektywna była płuczka 9, mająca w składzie 5,0\% środka B, której filtracja miała wartość $12,4 \mathrm{~cm}^{3}$ - o 56,8\% mniej niż w płuczce bazowej.

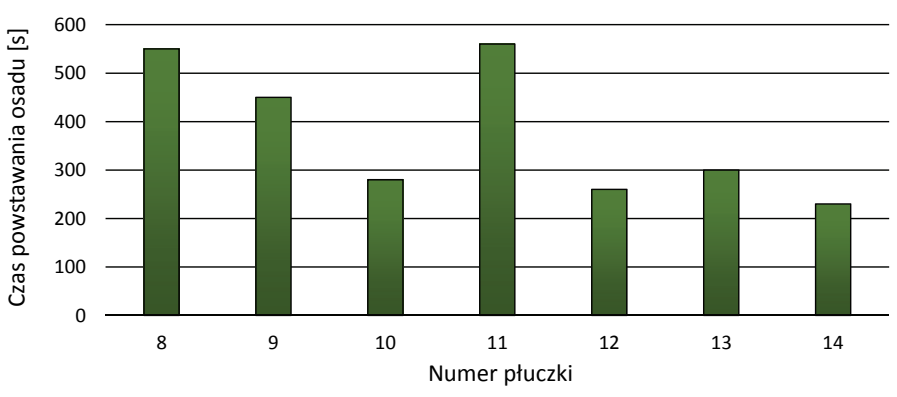

Rys. 17. Czas powstawania nieprzepuszczalnego osadu filtracyjnego w płuczkach 8-14 
Najdłuższy czas powstania nieprzepuszczalnego osadu filtracyjnego odnotowano podczas badania płuczki 11, było to około $560 \mathrm{~s}$, a więc więcej niż w płuczce bazowej. Najkrótszym czasem (około $230 \mathrm{~s}$ ) charakteryzowała się płuczka 14, zawierająca $20 \%$ blokatorów.

W tablicy 6 oraz na rysunku 18 zestawiono ze sobą wyniki pomiaru filtracji statycznej API w temperaturze $20^{\circ} \mathrm{C}$ z wynikami pomiaru filtracji dynamicznej HPHT w temperaturze $100^{\circ} \mathrm{C}$. Podobnie jak miało to miejsce podczas badania płuczek polimerowo-potasowych, wartości filtracji dynamicznej były zdecydowanie wyższe niż wartości filtracji API. W płuczce bazowej, w której nie było blokatorów węglanowych, filtracja dynamiczna miała wartość $28,7 \mathrm{~cm}^{3}$, co było wynikiem o około $395 \%$ wyższym od filtracji API równej $5,8 \mathrm{~cm}^{3}$. Z kolei w płuczce 14 filtracja dynamiczna była wyższa od filtracji API o około 108\%.
Tablica 6. Porównanie wyników badania filtracji API w $20^{\circ} \mathrm{C}$ oraz dynamicznej filtracji HPHT w $100^{\circ} \mathrm{C}$ pluczek $8-14$

\begin{tabular}{|l|c|c|c|c|c|c|c|}
\cline { 2 - 8 } \multicolumn{1}{c|}{} & \multicolumn{7}{c|}{ Nr phuczki } \\
\cline { 2 - 9 } \multicolumn{1}{c|}{} & 8 & 9 & 10 & 11 & 12 & 13 & 14 \\
\hline Filtracja API $\left[\mathrm{cm}^{3}\right]$ & 5,8 & 4,4 & 3,4 & 4,0 & 3,8 & 2,6 & 2,5 \\
\hline Filtracja HPHT $\left[\mathrm{cm}^{3}\right]$ & 28,7 & 12,4 & 8,3 & 11,6 & 10,3 & 6,2 & 5,2 \\
\hline
\end{tabular}

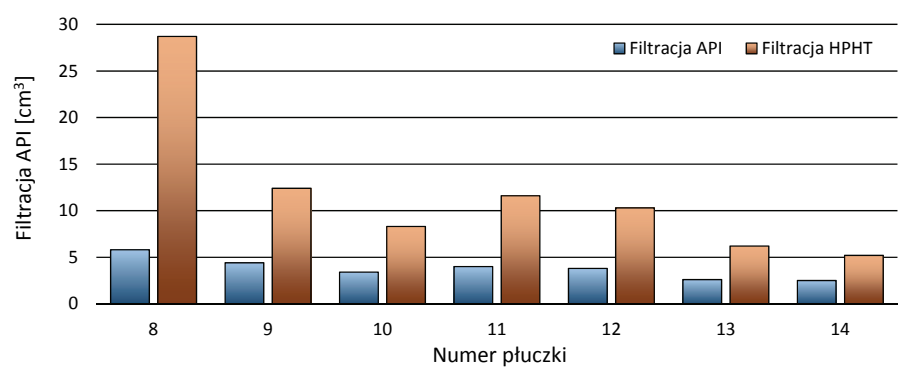

Rys. 18. Graficzne porównanie wyników badania filtracji API oraz dynamicznej filtracji HPHT płuczek 8-14

\section{Wnioski}

Analiza wyników przeprowadzonych badań pozwala sformułować następujące wnioski:

1. Płuczki glikolowo-potasowe i polimerowo-potasowe sporządzone w oparciu o ten sam zestaw koloidów ochronnych wyraźnie różnią się parametrami reologicznymi oraz filtracją. W temperaturze $20^{\circ} \mathrm{C}$, bazowa płuczka polimerowo-potasowa miała lepkość plastyczną równą $66,1 \mathrm{mPa} \cdot \mathrm{s}$, lepkość pozorną $106,8 \mathrm{mPa} \cdot \mathrm{s}$ oraz granicę płynięcia $39,0 \mathrm{~Pa}$. Wartości tych parametrów płuczki glikolowo-potasowej w takich samych warunkach były niższe i wynosiły odpowiednio $55,5 \mathrm{mPa} \cdot \mathrm{s}, 85,3 \mathrm{mPa} \cdot \mathrm{s}$ oraz 28,5 Pa. W przypadku filtracji API również płuczka glikolowo-potasowa charakteryzuje się niższym wynikiem $-5,8 \mathrm{~cm}^{3}$, w porównaniu do $6,4 \mathrm{~cm}^{3} \mathrm{w}$ płuczce polimerowo-potasowej.

2. Płuczka glikolowo-potasowa charakteryzuje się niższą filtracją dynamiczną w temperaturze $100^{\circ} \mathrm{C}$. Wartość filtracji HPHT w przypadku bazowej płuczki glikolowo-potasowej wynosiła $28,7 \mathrm{~cm}^{3}$, natomiast w płuczce polimerowo-potasowej było to $40,9 \mathrm{~cm}^{3}$. Taka sama zależność miała miejsce dla każdej pary płuczek zmodyfikowanych takim samym zestawem środków ograniczających filtrację.
3. Filtracja dynamiczna HPHT jest o wiele wyższa od filtracji statycznej API. Bazowa płuczka polimerowo-potasowa charakteryzowała się filtracją HPHT o 540\% wyższą od filtracji API. W przypadku płuczki glikolowo-potasowej różnica ta wynosiła 395\%. Różnica w wartości obu rodzajów filtracji zmniejszała się wraz z dodawaniem coraz większej liczby blokatorów. W płuczkach zawierających najbardziej efektywny z pośród badanych zestawów, czyli 10,0\% środka B oraz 10,0\% środka C, różnica w wielkości filtracji HPHT oraz API wynosiła $144 \%$ oraz $108 \%$ odpowiednio dla pluczki polimerowo-potasowej oraz glikolowo-potasowej.

4. Spośród wszystkich przebadanych kombinacji środków ograniczających filtrację, najbardziej skuteczny był zestaw $10 \%$ środka B oraz $10 \%$ środka C. Taka modyfikacja płuczki zapewniała ograniczenie filtracji API o $50 \%$ oraz filtracji dynamicznej HPHT o $80,9 \%$ w płuczce polimerowo-potasowej, oraz odpowiednio $56,9 \%$ i $81,9 \%$ w pluczce glikolowo-potasowej.

5. Charakterystyczne dla pomiarów filtracji dynamicznej przy użyciu aparatu M2200 było to, że po pewnym czasie, zależnym od składu płuczki, objętość filtratu przestawała narastać. 
Można wnioskować, że powstający na ściance rdzenia pomiarowego osad filtracyjny, stawał się coraz mniej przepuszczalny, aż do momentu w którym stawał się całkowicie nieprzepuszczalny. Literatura wskazuje [5, 11], że podczas badania filtracji w warunkach dynamicznych musi upłynąć okres od 6 do 15 godzin, aby wytworzył się szczelny osad. Prawdopodobną przyczyną tego, że filtrat przestawał przenikać przez rdzeń po tak krótkim czasie (w zależności od składu płuczki od około 200 do około 800 s) jest specyficzny kształt rdzenia i sposób w jaki oddziałuje na niego płuczka wiertnicza. W typowej dynamicznej prasie filtracyjnej osad filtracyjny tworzy się na płaskim, ceramicznym krążku lub papierze filtracyjnym, nad którym obraca się mieszadło wywołujące w komorze filtracyjnej ruch wirowy płuczki. W takich warunkach osad ulega ciągłej erozji, przez co narasta bardzo powoli. W urządzeniu Grace M2200 porowaty rdzeń symuluje ścianę otworu wiertniczego. Dodatkowo wewnątrz otworu rdzenia obraca się rotor wywołujący krążenie płuczki. Pod wpływem ruchu wirowego wewnątrz otworu, siła odśrodkowa może wyrzucać cząstki fazy stałej, które szybko tworzą zwarty, nieprzepuszczalny osad.

6. Czas wytworzenia osadu filtracyjnego uzależniony jest od stężenia i rodzajów środków ograniczających filtrację w płuczce. W płuczce bazowej polimerowo-potasowej, czas po którym objętość filtratu przestała się zmieniać, wynosił około 800 s. Po zmodyfikowaniu składu poprzez dodatek 5\% środka B, czas wytworzenia osadu skrócił się do około 460 s. Dalsze zwiększanie stężenia blokatorów powodowało dalsze skracanie czasu potrzebnego do wytworzenia osadu. Filtracja płuczki nr 7, gdzie w sumie znajdowało się 20\% blokatorów węglanowych, przestała się zwiększać już po około 200 s.

Prosimy cytować jako: Nafta-Gaz 2018, nr 2, s. 85-95, DOI: 10.18668/NG.2018.02.02

Artykuł nadesłano do Redakcji 24.11.2017 r. Zatwierdzono do druku 9.02.2018 r.

Artykuł powstał na podstawie pracy statutowej pt.: Badania laboratoryjne nad ograniczeniem filtracji ptuczek wiertniczych w dynamicznych warunkach HPHT - praca INiG - PIB na zlecenie MNiSW; nr zlecenia: 0062/KW/17, nr archiwalny: DK-4100-62/17.

\section{Literatura}

[1] Abdo J., Haneef M.D.: Clay nanoparticles modified drilling fluids for drilling of deep hydrocarbon wells. Applied Clay Science 2016, vol. 86, s. 76-82, DOI: 10.1016/j.clay.2013.10.017.

[2] Abdo J., Haneef M.D.: Nano-enhanced drilling fluids: pioneering approach to overcome uncompromising drilling problems. Journal of Energy Resources Technology 2012, vol. 134, nr 1, 014501, DOI: $10.1115 / 1.4005244$.

[3] Adel M., Ragab S., Noah A.: Reduction of formation damage and fluid loss using nano-sized silica drilling fluids. Petroleum Technology Development Journal: An International Journal 2014, vol. 2, nr 7, s. 75-88.

[4] Bielewicz D.: Ptyny wiertnicze. Wydawnictwa AGH, Kraków 2009.

[5] Budak P., Falkowicz S.: Statyczna i dynamiczna filtracja pluczek wiertniczych - porównawcze studium eksperymentalne. Nafta-Gaz 2000, nr 7-8, s. $420-427$.

[6] Contreras O., Hareland G., Husein M., Nygaard R., Al-Saba M.: Application of in-house prepared nanoparticles as filtration control additive to reduce formation damage. SPE-168116-MS, 2014, DOI: 10.2118/168116-MS.

[7] Dębińska E., Niekonwencjonalne zaczyny cementowe z dodatkiem nanokrzemionki. Nafta-Gaz 2015, nr 5, s. 290-300.

[8] Dębińska E.: Wplyw nanokrzemionki na parametry mechaniczne kamienia cementowego. Nafta-Gaz 2014, nr 4, s. 229-235.

[9] Jankiewicz B.J., Choma J., Jamioła D., Jaroniec M.: Nanostruktury krzemionkowo-metaliczne. Otrzymywanie i modyfikacja nanoczastek krzemionkowych. Wiadomości Chemiczne 2010, nr 64, s. 913-942.

[10] Kalantariasl A., Zeinijahromi A., Bedrikovetsky P.: External filter cake buildup in dynamic filtration: mechanisms and key factors. SPE-168144-MS, 2014, DOI: 10.2118/168144-MS.

[11] M-I Drilling Fluids: Podręcznik inżynierii płuczek wiertniczych. Kraków 1996.

[12] Ozyurtkan M.H., Altun G., Osgouei A.E., Aydilsiz E.: Dynamic filtration properties of clay based drilling muds under elevated temperatures. SPE-163325-MS, 2012, DOI: 10.2118/163325-MS.
[13] Ponmani S., Nagarajan R., Sangwai J.S.: Effect of nanofluids of $\mathrm{CuO}$ and $\mathrm{ZnO}$ in polyethylene glycol and polyvinylpyrrolidone on the thermal, electrical, and filtration-loss properties of water-based drilling fluids. SPE-178919-PA, 2016, DOI: 10.2118/178919-PA.

[14] Salih A.H., Bilgesu H.: Investigation of rheological and filtration properties of water-based drilling fluids using various anionic nanoparticles. SPE-185638-MS, 2017, DOI: 10.2118/185638-MS.

[15] Salih A.H., Elshehabi T.A., Bilgesu H.I.: Impact of nanomaterials on the rheological and filtration properties of water-based drilling fluids. SPE-184067-MS, 2016, DOI: 10.2118/184067-MS.

[16] Salmachi A., Talemi P., Tooski Z.Y.: Psyllium husk in water-based drilling fluids: an environmentally friendly viscosity and filtration agent. SPE-183308-MS, 2016, DOI: 10.2118/183308-MS.

[17] Strona internetowa: http://bdc.com.pl (dostęp: wrzesień 2016).

[18] Strona internetowa: http://www.glossary.oilfield.slb.com (dostęp: wrzesień 2016).

[19] Strona internetowa: http://www.pspw-krosno.com.pl (dostęp: sierpień 2016).

[20] Vipulanandan C., Raheem A., Basirat B., Mohammed A.S., Richardson D.A.: New kinetic model to characterize the filter cake formation and fluid loss in HPHT process. OTC-25100-MS, 2014, DOI: $10.4043 / 25100-\mathrm{MS}$.

[21] Wiercinski S.: The Use of walnutshell filtration with enhanced media for reduction and/or elimination of upstream produced water treatment equipment. SPE-184893-MS, 2017, DOI: 10.2118/184893-MS.

[22] Zima G.: Analiza wpływu nanomateriatów na właściwości osadu filtracyjnego. Nafta-Gaz 2017, nr 5, s. 312-320, DOI: 10.18668/ NG.2017.05.03.

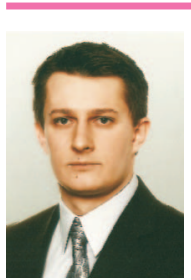

Mgr inż. Bartłomiej JASIŃSKI

Asystent w Zakładzie Technologii Wiercenia.

Instytut Nafty i Gazu - Państwowy Instytut Badawczy

ul. Lubicz $25 \mathrm{~A}$

31-503 Kraków

E-mail: bartlomiej.jasinski@inig.pl 